\title{
Studies on Bio-chemical Changes in Dry Root Rot (Macrophomina phaseolina) Infected Plants of Mungbean (Vigna radiata L.)
}

\author{
Mohit Kumar ${ }^{1 *}$, Data Ram Kumhar ${ }^{1}$, Pradeep Kumar ${ }^{2}$ and Kiran Choudhary ${ }^{1}$ \\ ${ }^{1}$ Department of Plant Pathology, College of Agriculture, Bikaner, India \\ ${ }^{2}$ Agricultural Research Station, Sri Ganganagar \\ Swami Keshwanand Rajasthan Agricultural University, Bikaner-334006, Rajasthan, India
}

*Corresponding author

\section{A B S T R A C T}

Keywords

Total sugar, Protein, Phenols, Mungbean, Varietal wealth

Article Info

Accepted:

17 December 2018 Available Online: 10 January 2019
Mungbean (Vigna radiata L.) also known as green gram, is an important pulse crop providing vegetable protein for people throughout the world. It is being suffered by several fungal, bacterial and viral diseases but dry root rot of mungbean incited by Macrophomina phaseolina (Tassi) Goid. is the most common problem in mungbean growing areas of Rajasthan (India). The total sugar, reducing sugar, non reducing sugar and soluble protein were higher in healthy roots as compared to diseased roots in all the tested varieties i.e., SML-668, MH-2-15 and IPM-02-03. Maximum reduction in total sugar, reducing sugar, non reducing sugar and soluble protein was found in SML-668 followed by MH-2-15, while total phenol content was higher in diseased roots as compared to healthy tissues of all the tested varieties. Maximum increase in total phenol was observed in diseased roots of SML-668 followed by MH-2-15.

\section{Introduction}

Mungbean (Vigna radiata L.) is one of the most ancient and extensively grown leguminous crops of India. It has proved to be an ideal crop for spring and summer/ kharif season. Mungbean belongs to family leguminosae and sub family papilionaceae. It is a short duration crop and rich in protein and vitamin B. It contains 24.5 per cent protein and 59.9 per cent carbohydrate. It also contains $75 \mathrm{mg}$ calcium, $8.5 \mathrm{mg}$ iron and 49 mg R-carotrne per $100 \mathrm{~g}$ of split dual (Bhowaland and Bhowmik, 2014). It has the capacity to fix atmospheric nitrogen through symbiotic nitrogen fixation. It is also used as green manure crop. Mungbean is prove to fungal disease, among them dry root rot incited by Macrophomina phaseolina is a soil borne pathogen. Macrophomina phaseolina survives in/on seed and persisted in the soil in the form of black sclerotia which are produced in large number on infected host tissues and are subsequently dispersed in soil during tillage operations (Sheikh and Ghaffar, 1978).

\section{Materials and Methods}

\section{Estimation of total sugars}

\section{Reagents}

Anthrone reagent $(2 \mathrm{mg} / \mathrm{ml}$ conc, sulphuric acid) 
Standard glucose solution $(1 \mathrm{mg} / \mathrm{ml})$ : dissolved $100 \mathrm{mg}$ glucose in $100 \mathrm{ml}$ distilled water.

Working standard solution $(100 \mathrm{mg} / \mathrm{ml})$ Dilute $10 \mathrm{ml}$ standard solution to $100 \mathrm{ml}$ with distilled water.

$5 \mathrm{~N} \mathrm{HCI}$

Total sugar content was determined by colorimetric method using anthrone reagent. In this method, $100 \mathrm{mg}$ of sample was taken in a boiling tube and hydrolyzed it in boiling water bath for $3 \mathrm{~h}$ with $5 \mathrm{ml}$ of $2.5 \mathrm{~N} \mathrm{HCI}$ and cooled to room temperature neutralized it with solid sodium carbonate until the effervescence ceased and made the volume to $100 \mathrm{ml}$ and centrifuged, collected the supernatant and took 0.5 and $1 \mathrm{ml}$ aliquots for analysis, then prepared the standards by taking $0,0.2,0.4$, $0.6,0.8$ and $1 \mathrm{ml}$ of working standard and made the volume to $1 \mathrm{ml}$ in all the tubes including the sample tubes by adding distilled water, after that $4 \mathrm{ml}$ of anthrone reagent was added, heated for $8 \mathrm{~min}$ in a boiling water bath, cooled it rapidly and read the green to dark green colour at $630 \mathrm{~nm}$. The amount of sugars present in the sample was plotted against standard curve prepared from glucose. The sugar content in plant samples was expressed as $\mathrm{mg} \mathrm{g}^{-1}$ fresh tissue (Dubois et al., 1956).

\section{Estimation of reducing sugars}

\section{Reagents}

\section{Copper reagent " $\mathrm{A}$ "}

Sodium carbonate (anhydrous)

Potassium sodium tartrate

$2.5 \mathrm{~g}$

Sodium bi-carbonate

Sodium sulphate

Distilled water

Volume

\section{Copper reagent "B"}

Copper sulphate

$15 \mathrm{~g}$

Conc. sulphuric acid

Volume

1 drop

$100 \mathrm{ml}$

\section{Alkaline copper tartrate}

Copper reagent "A"

Copper reagont "B"'

$24 \mathrm{ml}$

$1 \mathrm{ml}$

\section{Arseno-molybdate reagent}

Ammonium molybdate

$2.5 \mathrm{~g}$

Conc. Sulphuric acid

$2.5 \mathrm{ml}$

Di-sodium hydrogen arsenate

Volume

$0.3 \mathrm{~g}$

$70 \mathrm{ml}$

Standard glucose solution (1 $\mathrm{mg} / \mathrm{ml})$ Dissolve $100 \mathrm{mg}$ glucose in $100 \mathrm{ml}$ distilled

Working standard solution $(100 \mathrm{mg} / \mathrm{ml})$-Dilute $10 \mathrm{ml}$ standard solution to $100 \mathrm{ml}$ with distilled water

Reducing sugar content was measured following "Nelson's modification of somogyi's method" (Somogyi,1952) using arsenomolybdate colour forming reagent and two copper reagent "A" and "B", In this $100 \mathrm{mg}$ of sample was taken and extracted the sugars with hot $80 \%$ alcohol twice, collected the supernatant and evaporated on sugar bath, added $10 \mathrm{ml}$ water and dissolved the sugars, pipetted out aliquots of 0.1 or $0.2 \mathrm{ml}$ of alcohol-free extract to separate test tubes. Then pipette out $0.2,0.4,0.6,0.8$ and $1 \mathrm{ml}$ of the working standard solution into a series of test tubes, made up the volume in both samples and standard tubes to $2 \mathrm{ml}$ with distilled water, pipette out $2 \mathrm{ml}$ distilled water into a separate tube to serve as a blank, added $1 \mathrm{ml}$ of alkaline copper tartarate reagent to each tube, placed the tubes in a boiling water for $10 \mathrm{~min}$, cooled the tubes and added $1 \mathrm{ml}$ of arsenomolybdic acid reagent to all the tubes. 
Made the volume in each tube to $10 \mathrm{ml}$ with water and absorbance was measured at 620 $\mathrm{nm}$ on Spectronic-20. The value was plotted against a standard curve prepared from glucose. The figures were expressed on percentage basis.

\section{Estimation of non- reducing sugar}

The amount of non-reducing sugar was obtained by subtracting reducing sugar from the amount of total sugars and multiplying the resultant with a constant factor 0.95 .

\section{Estimation of total phenol content}

The total phenol content was estimated by the method described by Thimmaiah (1999). One gram root or shoot sample was grind in mortar and pestle with $10 \mathrm{ml} 80$ per cent ethanol. The homogenate was centrifuged at 10,000 rpm for 20 minutes. The supernatant was filtered and the residue was re-extracted with five-time volume of 80 per cent ethanol, supernatant was cooled and evaporated to dryness in water bath. The residue was dissolved in $5 \mathrm{ml}$ of distilled water. An aliquot of $0.2 \mathrm{ml}$ was transferred in test tube and volume was made to $3 \mathrm{ml}$ with distilled water, Folin-ciocalteau reagent $(0.5 \mathrm{ml})$ was added in each test tube. After three minutes, $2 \mathrm{ml}$ of 20 per cent sodium carbonate was added in each tube and mix thoroughly. The tubes were then placed in boiling water for one minute. After cooling, the absorbance was recorded at $650 \mathrm{~nm}$ against a reagent blank. The standard curve was prepared by taking different concentrations of catechol. The phenol content was express as $\mathrm{mg} \mathrm{g}^{-1}$ fresh tissue.

\section{Estimation of soluble protein content}

The soluble protein content of the samples was assayed by using the method of Lowry et al., (1951). One gram of root or shoot was macerated in mortar with $5 \mathrm{ml} 0.1 \mathrm{M}$ sodium phosphate buffer ( $\mathrm{pH} 7.0$ ). The homogenate was centrifuged of $16,000 \mathrm{~g}$ for 20 minutes. The supernatant was used for estimation of soluble protein content. For this purpose, two per cent sodium carbonate (anhydrous) in 0.1 $\mathrm{N} \mathrm{NaOH}$ (Solution A) was prepared. Similarly, 0.5 per cent copper sulphate $\left(\mathrm{CuSO} 4 \cdot 5 \mathrm{H}_{2} \mathrm{O}\right)$ in 1 per cent sodium potassium tartarate (freshly made) was prepared (solution B). From these two reagents, solution $\mathrm{C}$ (alkaline copper sulphate) was prepared by mixing $50 \mathrm{ml}$ of solution A with $1 \mathrm{ml}$ of solution B just before use. An aliquot of $0.1 \mathrm{ml}$ supernatant was taken in test tube and the volume was made to $1 \mathrm{ml}$ with distilled water followed by addition of $5 \mathrm{ml}$ solution $\mathrm{C}$ mixed well and incubated at room temperature for ten minutes. A 0.5 milliliter of folin ciocalteu reagent was diluted to $1 \mathrm{~N}$, mixed well and incubated at room temperature in dark for 30 minutes. The absorbance was recorded at $660 \mathrm{~nm}$ against blank. The amount of protein in sample was computed from the standard curve prepared by using different concentrations of bovine serum albumin. It was expressed as part per million (ppm).

\section{Results and Discussion}

\section{To study the bio-chemical changes in infected plant parts of mungbean}

To study the biochemical change in total sugars, reducing and non- reducing sugars, soluble protein and total phenols from dry root rot infected roots compared with roots of healthy plant and estimated in the laboratory.

Dry root rot infestation resulted in significant reduction in total sugars, reducing and nonreducing sugars contents of mungbean roots. Data of table 1 revealed that total sugar content was observed low in diseased plant roots as compared to healthy roots of all the test varieties. Maximum decrease in total sugar was observed in infected roots of SML- 
$668(14.13 \%)$ followed by $\mathrm{MH}-2-15(7.72 \%)$ and IPM-02-03 (7.50\%), respectively. The similar trend was also found in reducing and non reducing sugar. In the present studies, total, reducing and non reducing sugars were observed to be low in disease infected roots as compared to healthy roots of plant (Fig. 1).

There was a significant decrease in soluble protein content in diseased roots as compared to healthy roots in all the tested varieties, Maximum reduction in soluble protein was observed in SML-668 (27.96\%) followed by MH-2-15 (17.48\%) and IPM-02-03 (15.00\%). The data indicate that the soluble protein was observed more in healthy roots compared to diseased root. The results concluded by Pancham Arya et al., (2016) reported the reduction in the contents of total sugars, reducing and non-reducing sugars in the roots of dry root rot disease caused by Macrophomina phaseolina in groundnut, and they also found that soluble protein content were significantly decreased in diseased roots of groundnut. These finding are very much similar with our finding.
The results are in agreement with the findings of Ushamalini et al., (1998). The reduction in sugars content after infection may be due to rapid hydrolysis of sugars during pathogenesis through enzymes (hydrolases) secreted by pathogens and subsequent utilization by pathogen for their development.

Verma and Singh (1994) and Sultana et al., (1998) reported higher amount of sugars in healthy plant parts as compared to diseased ones. The same findings were also in cowpea seeds due to infection by seed borne fungi.

There was a significant increase in phenol content of mungbean roots due to dry root rot as compared healthy roots after 45 days sowing. Maximum phenolic content Increased in diseased root of SML-668 (44.36\%) followed by MH-2-15 (25.85\%) and IPM-02$03(14.66 \%)$ as compared to respective healthy roots. Findings revealed that total phenols in all the varieties were found to be higher due to infection (Fig. 2 and Table 2).

Table.1 Bio-chemical changes on total sugars, reducing and non-reducing sugars in infected roots of mungbean

\begin{tabular}{|l|c|c|c|c|c|c|}
\hline \multirow{2}{*}{ Variety } & \multicolumn{2}{|c|}{$\begin{array}{c}\text { Total sugar } \\
\text { (mg/g fresh tissue) }\end{array}$} & \multicolumn{2}{c|}{$\begin{array}{c}\text { Reducing sugars } \\
\text { (mg/g fresh tissue) }\end{array}$} & \multicolumn{2}{c|}{$\begin{array}{c}\text { Non-reducing } \\
\text { (mg/g fresh tissue) }\end{array}$} \\
\cline { 2 - 7 } & Healthy & Diseased & Healthy & Diseased & Healthy & Diseased \\
\hline IPM-02-03 & 6.80 & $\begin{array}{c}6.29 \\
(-7.50)\end{array}$ & 4.35 & 3.93 & 2.38 & 2.24 \\
& & 6.09 & 4.20 & 3.80 & 2.28 & 2.18 \\
\hline MH-2-15 & 6.60 & $(-7.72)$ & & $(-9.65)$ & & $(-7.89)$ \\
\hline SML-668 & & 4.98 & 3.72 & 3.21 & 1.97 & 1.69 \\
& 5.80 & $(-14.13)$ & & $(-13.70)$ & & $(14.21)$ \\
\hline S.Em \pm & 0.11 & 0.11 & 0.13 & 0.19 & 0.15 & 0.18 \\
CD P=0.05 & 0.34 & 0.33 & 0.42 & 0.57 & 0.45 & 0.57 \\
CV (\%) & 1.68 & 1.74 & 2.55 & 5.10 & 3.85 & 5.00 \\
\hline
\end{tabular}

*values in parentheses indicate per cent deviation in diseased roots over healthy roots of corresponding variety 
Table.2 Bio-chemical changes on soluble protein and total phenols in infected roots of mungbean

\begin{tabular}{|c|c|c|c|c|}
\hline \multirow[t]{2}{*}{ Variety } & \multicolumn{2}{|c|}{$\begin{array}{c}\text { Soluble protein } \\
\text { (mg/g fresh tissue) }\end{array}$} & \multicolumn{2}{|c|}{$\begin{array}{c}\text { Total phenols } \\
\text { (mg/g fresh tissue) }\end{array}$} \\
\hline & Healthy & Diseased & Healthy & Diseased \\
\hline IPM-02-03 & 14.40 & $\begin{array}{c}12.24 \\
(-15.00)^{*}\end{array}$ & 1.50 & $\begin{array}{c}1.72 \\
(14.66)\end{array}$ \\
\hline MH-2-15 & 13.90 & $\begin{array}{c}11.47 \\
(-17.48)\end{array}$ & 1.47 & $\begin{array}{c}1.85 \\
(25.85)\end{array}$ \\
\hline SML-668 & 11.80 & $\begin{array}{c}08.50 \\
(-27.96)\end{array}$ & 1.42 & $\begin{array}{c}2.05 \\
(44.36)\end{array}$ \\
\hline $\begin{array}{c}\text { S.Em } \pm \\
\text { CD P=0.05 } \\
\text { CV }(\%)\end{array}$ & $\begin{array}{l}0.20 \\
0.54 \\
4.47\end{array}$ & $\begin{array}{l}0.11 \\
0.33 \\
4.40\end{array}$ & $\begin{array}{l}0.19 \\
0.58 \\
5.10\end{array}$ & $\begin{array}{c}0.036 \\
0.114 \\
3.05\end{array}$ \\
\hline
\end{tabular}

*values in parentheses indicate per cent deviation in diseased roots over healthy roots of corresponding variety

Fig.1 Bio-chemical changes on total sugars, reducing and non-reducing sugars in infected roots of mungbean

\begin{tabular}{|ccc}
\hline Total sugar & Reducing sugar & Non reducing \\
& & 14.21 \\
& 7.89 & 13.7 \\
5.88 & 9.65 & 14.13 \\
9.52 & 7.72 & \\
7.5 & & SML-668 \\
\hline IPM-02-03 & MH-2-15
\end{tabular}

Fig.2 Bio-chemical changes on soluble protein and total phenols in infected roots of mungbean

\begin{tabular}{|c|c|c|c|}
\hline & & & 44.36 \\
\hline & 25.85 & & 27.96 \\
\hline 14.56 & 17.48 & & \\
\hline \multirow[t]{2}{*}{ IPM-02-03 } & MH-2-15 & & SML-668 \\
\hline & PROTEIN & PHENOL & \\
\hline
\end{tabular}


Phenolic compound are fungitoxic in nature; hence the accumulation of phenolic compound increase the physical and mechanical strength of host cell wall resulting in the inhibition of fungal invasion (Benhamou et at., 2000). The phenol and proline compound act as adaptive mechanism in the host plant against the fungal infection. Phenolic substances are known to participate in a number of bio-chemical process, such a oxidation reduction reaction and stimulation as well as inhibition of auxin activity (Misaghi, 1982). Phenolic compounds were sown inhibit the production of cell wall degrading enzymes by the pathogen (Mandavia et al., 1997).

The total phenol contents showed an increase in the roots of infected plants compared to those of healthy plants. Accumulation of phenolic compounds at the infection site has been correlated with the restriction of pathogen development, since such compounds are toxic to pathogens. Also, phenolic compounds may impede pathogen infection by increasing the mechanical strength of the host cell wall (Benhamou et al., 2000).

In conclusion it is clear from the data that total sugar, reducing, non reducing and soluble protein was higher in healthy roots as compared to diseased roots in all the tested varieties. Among the varieties, maximum reduction in total sugar, reducing, non reducing and soluble protein was found in SML-668 followed by MH-2-15, while total phenol content was higher in diseased roots as compared to healthy tissue. Among the varieties, maximum increase in total phenol was observed in diseased roots of SML-668 followed by MH-2-15.

\section{References}

Bhowaland SK and Bhowmik SK. 2014. Performance of summer mungbean as affected by variety and date of harvest trends in biosciences. 7(13): 15-34.

Sheikh, A. H. and Ghaffer, A. 1978. Relation of sclerotial inoculum density and soil moisture to infection of field crops by Macrophomina phaseolina. Pak. J. Bot. 11: 185-189.

Dubois, M. Gilles, K. A. Hamilton, J. K. Rebers, P. A. and Smith, F. 1956. Calorimetric method for determination of sugars and related substances. Anal. Chem. 28(3): 350- 356.

Somogyi, M. 1952. Notes on sugar estimation. J. Biol. Chem. 200(5): 245.

Thimmaiah, S. K. 1999. Standard Methods of Biochemical Analysis, Kalyani Publishers, Noida.

Lowry, O.H Rosenbrough, N. J,Farr, A. Randall, R.J. 1951 protein measurement with the Folin phenol reagent. J. Biol. Chem. 193(1): 265275.

Pancham Arya, Meena, A. K., Bimla. 2016. Study of biochemical changes viz., total sugars (reducing and nonreducing), proteins and phenols in dry root rot infected groundnut plant. Annals of Biology. 32(2):188-192.

Ushamalini, C., Rajappan, K. and Gangadharan, K. 1998. Changes in the biochemical constituents of cowpea due to seedborne fungi. Ind. Phytopath. 51(3): 258-260.

Verma, K. S. and Singh, T. 1994, Blochemical alterations in grey blight affected leaves of mango. Pl. dis. Res. 9: 29-34.

Sultana, N, Kasem, M. A., Hussain, M. D. and Alam, M. S. 1998. Biochemical changes of some promising lines of yard long bean due to infection of yellow mosaic virus. Thai. J. agric. Sci., 31: 322-327.

Benhamou, N., Gagne, S., Quere, D. L. and Dehbi, L. 2000. Bacterial mediated induced resistance in cucumber: 
Beneficial effect of the endophtic bacterium Serratia plymuthica on the protection against infection by Pythium ultimum. Phytopathol. 90: 45-56.

Misaghi, J. 1982. Alternations in phenol metabolism caused by disease. Physiology and Biochemistry of PlantPathogen Interactions. Springer
Publisher, US. pp. 103-111.

Mandavia, M. K., Patel, C. M, Maravia, G. V., and Arameswaran, M. P. 1997. Role of phenolic compounds in resistance to Fusarium wilt in chickpea. Ind. J. Agril. Biochem. 10(1\&2): 11-13.

\section{How to cite this article:}

Mohit Kumar, Data Ram Kumhar, Pradeep Kumar and Kiran Choudhary. 2019. Studies on Bio-chemical Changes in Dry Root Rot (Macrophomina phaseolina) Infected Plants of Mungbean (Vigna radiate L.). Int.J.Curr.Microbiol.App.Sci. 8(01): 2401-2407. doi: https://doi.org/10.20546/ijcmas.2019.801.253 